\title{
Når politisk kontrol forringer forsvaret
}

\section{Henning Sørensen}

Demokratisk kontrol med forsvaret er et nøglebegreb i militærsociologien. Denne videnskabsgren anskuer forsvaret ud fra et nationalt perspektiv og fokuserer på den militære profession, organisation, krigens sociologi og forsvarsplanlægning/strategi. Hvor militærpsykologen hjælper majoren med at styre den menige, og militærpolitologen hjælper Danmark med at styre verden, hjælper militærsociologen samfundet med at styre forsvaret.

Danske politikeres kontrol med forsvaret har nu nået et kritisk punkt. Den svækker ganske enkelt forsvarets effektivitet og det på alle fem militærsociologiske parametre. Det har politikerne kunnet gøre - stort set ubemærket - fordi militærsociologien er blevet nedprioriteret. Det fremgår af en hurtig optælling af de tre typer militærforskere.

Der er 59 militærpsykologer på Forsvarsakademiet, FAK, én militærsociolog, men nok er over 40 militærpolitologer. Der er 74 forskere på Dansk Institut for Internationale Studier, DIIS, hovedparten er militærpolitologer. Endelig er der 14 militærpolitologer på Center for Militære Studier, CMS, Københavns Universitet.
Problemet er ikke kun, at man har fravalgt den militærsociologiske forskning, men også at de ca. 100 militærpolitologer undlader at undersøge forsvaret, endsige kritisere det - og sjældent hinanden indbyrdes. Intet andet vestligt land har så suverænt fravalgt militærsociologisk indsigt, analyse og kritik. Det har muliggjort, at politikerne har kunnet forringe forsvarets effektivitet uimodsagt.

\section{Den militære profession}

Det første sted denne overpolitisering af forsvaret har fundet sted er mod den militære profession, altså de soldater og civile der er ansat i forsvaret i et længere livsforløb. Forsvarets personeludvikling over de sidste ca. 50 år viser, at i 1970 var 55.100 mennesker beskæftiget i forsvaret. Officerer, befalingsmænd og kontraktansatte konstabler udgjorde 33 pct., værnepligtige 44 pct. og civilt-ansatte 23 pct. I dag er der 19.900 personer. Nu udgør de professionelle soldater 68 pct., værnepligtige 10 pct. og civilt ansatte 22 pct. Andelen af professionelle soldater i forsvaret er altså mere end fordoblet. Den øgede andel af professionelle soldater nødvendiggøres af de komplekse missioner, vi sender vore soldater ud i.

For godt ti år siden besluttede politi-

Henning Sørensen er militærsociolog, ph.d., cand.mag. og cand.scient.pol. 
FOTO: U.S. Air Force photo/Senior Airman R. Alex Durbin

Den danske regering indgik i 2016 en aftale med Socialdemokraterne, Dansk Folkeparti, de Radikale og Liberal Alliance om at købe 27 kampfly af typen F-35. 
kerne at reducere værnepligtiges uddannelsestid, og ved det seneste forsvarsforlig har de reduceret officersuddannelserne fra tidligere mellem 47-65 måneder til nu blot 28 . Disse politiske indgreb vil være uhørte på de civile højere læreanstalter. Man kan ikke halvere uddannelsestiden for et akademisk studie uden at skade professionens effektivitet.

Dertil kommer grundlaget for rekruttering af officerer. Tidligere kom kadetterne ind på officersskolerne fra geledtjeneste eller civil relevant praksis for militæret. I dag tillades en bachelor i fx teatervidenskab eller litteratur optagelse på officersstudiet. Den rekrutteringsmodel er uhensigtsmæssig for en institution, hvor knap 70 pct. er professionelle soldater.

Ældre officerer vil møde unge kolleger, som må savne den militære professions æresbegreb, etik, korpsånd og broderskabsfølelse. De her nævnte politiske tiltag svækker den militære professions selvforståelse og dermed forsvarets slagmarkseffektivitet.

\section{Den militære organisation}

Det er velkendt, at danske politikere har forringet forsvarets effektivitet økonomisk. I 1970 brugtes 2,4 pct. af BNP til militære formål, i dag 1,2 pct. Som andre offentlige institutioner skal forsvaret også spare. Men det er ikke kun sat til at spare, det har oplevet en økonomisk rutsjebanetur fra nedskæring for 2014-2017 med 2,7 mia. kr. efter en forudgående bevillingsforøgelse for 2010-2014 på 3,5 mia. $\mathrm{kr}$. Den slags udsving forringer en professionel planlægning.

Samtidigt hævder forligskredsen af politikere, at indkøb af 27 kampfly til 20 mia. kr. kan holdes inden for det nuværende stramme forsvarsbudget.
Det er ikke muligt. Alligevel stiller regeringen og forsvarsminister Claus Hjort Frederiksen forsvaret i udsigt, at det skal tildeles flere midler. Men det er til at dække de stigende udgifter til PTSD-veteraner. Beregninger fra USA indikerer, at udgifterne til psykisk skadede veteraner i Danmark vil stige frem til ca. år 2050 og kan komme op på samme niveau som de umiddelbare militære krigsomkostninger. Krigsindsatsen i Irak kostede 2,5 mia. kr., i Afghanistan 11,5 mia. kr. frem til 2014. Dertil kommer en udviklingshjælp til Afghanistan på 3,5 mia. kr. tillige med over én mia. kr. brugt på troppetransporter samt to mia. kr. for danske soldaters indsats dér efter 2014.

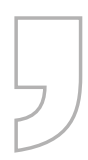

\section{Med de politiske beslutninger om at udnævne tre hærofficerer lige efter hinanden som FC må de to små blå værn, søværn og flyvevåben, føle sig tilsidesat.}

De betydelige udgifter til internationale missioner har politikerne så yderligere ønsket at sløre. Fra 2012 opgøres udsendelsesudgifterne nu på den måde, at de internationale operationer kun skal belastes med merudgifterne, så som soldaters udstationeringstillæg, forsikringspræmier, etc., mens grundløn udelukkes. Det vanskeliggør sammenligninger over tid, landegrænser og tjenestegrene. Det er en opgørelsesmåde, der er fuldstændig fremmed i andre offentlige virksomheder, og fraværet af sammenligninger svækker også her den militære effektivitet.

Et andet nyligt politisk indgreb i det danske forsvars organisation er proceduren ved valg af forsvarschef (FC). Siden 1945 og frem til 2009 er FC-stillingen bortset fra få undtagelser - gået på skift mellem de tre værn efter en indstilling 
fra topcheferne i forsvaret, en indstilling som politikerne så fulgte. Men med de seneste tre FC-er, også kaldet hærens tre B'er - Bartels, Bartram og Bisserup - er denne topkarriere-procedure ophørt.

Med de politiske beslutninger om at udnævne tre hærofficerer lige efter hinanden som FC må de to små blå værn, søværn og flyvevåben, føle sig tilsidesat. Proceduren indsnævrer også FC’s synsvinkel på det samlede forsvar, ligesom den tidligere, brede accept i forsvaret af FC-valget lider herunder; alt sammen noget der svækker den militære effektivitet.

\section{Civilt-militære relationer}

De civilt-militære relationer i 1970’erne - under Vietnamkrigen og efter - var præget af folkelig afstandtagen, grænsende til mistillid. Jeg husker fra min tid som timelærer på Søværnets Officersskole, hvordan søofficerer pendlede i civil for at undgå ubehagelige kommentarer fra medrejsende og til middagsselskaber blot fortalte, at de var offentligt ansatte, ikke professionelle soldater. Politikerne dengang var ikke særligt positive indstillet over for forsvaret. De var stort set kun optaget af forsvarets økonomi og behandling af værnepligtige, der blev set som en gavnlig demokratisk indflydelse på den militære verden.

I dag er holdningen klart mere positiv. $\mathrm{Nu}$ fremhæver politikerne vore udsendte soldater og har indstiftet en flagdag den 5. september hvert år til ære for dem. Ja, mere end det. Politikerne, for det kan kun være dem, opfordrer os borgere til 'Støt vore soldater.' Man kan argumentere for, at det er borgerne, der indbyrdes opfordrer hinanden hertil. Men så postuleres, at nogle borgere ikke vil støtte vore soldater. Og det er ikke korrekt. Man kan heller ikke udlede af udsagnet, at det er soldaterne selv, der beder om støtte. Så havde sloganet lydt 'Støt os soldater'.

Men flere forhold ved opfordringen kan undre: Hvorfor behøver stærke udsendte soldater støtte? Den har de vel fået inden, under og efter udsendelse - af politikerne? Hvorfor skal vore soldater tildeles en fortrinsstilling i forhold til andre offentligt ansatte i politi, beredskab, brandvæsen, hospitaler, osv.? De har da også ret til og behov for støtte. Og hvilken konkret eller moralsk støtte har de udsendte soldater særlig brug for fra os borgere?

Opfordringen virker hul, når man betænker, hvordan politikerne i øvrigt behandler 'vore soldater'. Med den placerer politikerne soldaterne foran sig og går selv i flyverskjul, skulle deres beslutning om at udsende 'vore soldater' til internationale missioner blive kritiseret.

I realiteten har politikerne fået en blanco-check fra befolkningen for sine udsendelsesbeslutninger. Nok giver en sådan 'nul-kritik-check' politikerne 'arbejdsro', men den er skadelig for den demokratiske debat og svækker dansk forsvars slagmarkseffektivitet.

\section{Krigens sociologi}

Typen af internationale missioner, som danske soldater er sendt ud til, har skiftet karakter. I første periode fra 1948 til 1992 deployeredes danske soldater til længerevarende, men lavintensive konflikter ledet af FN. Fra 1992 til 2010 udsendtes et betydeligt antal soldater til længerevarende, højintensive krige på Balkan (1992 - 2003, 1999 - 2009), i Irak (2003 - 2007) og Afghanistan (2003 2014) først ledet af FN, senere USA.

Men fra omkring $2010 \mathrm{og}$ frem sendes især danske fly- og hærenheder nu til kortere, mindre højintensive konflik- 
ter i Irak, Mali, Syrien, Afghanistan. I dag fungerer vore hærstyrker ikke som egentlige kamptropper, men mest som instruktører. Den store forskel for Danmark er ikke kun, at vi siden 1992 er blevet en eksportør af tropper, hvor vi under den kolde krig var importør af troppeforstærkninger fra UK og USA, men nok så meget at strategien bag udsendelsen er gået fra at afveje politiske konsekvenser af mulige militære troppeforstærkninger til at udsende soldater for politisk at 'please' først FN og senere USA.

Dermed fjernes muligheden for at høre den militære ekspertise om, hvor danske styrker bedst gør nytte? Det afgøres alene af politikerne, men igen uden noget afbalanceret input fra anden side.

Hvor dominerende den politiske domi-

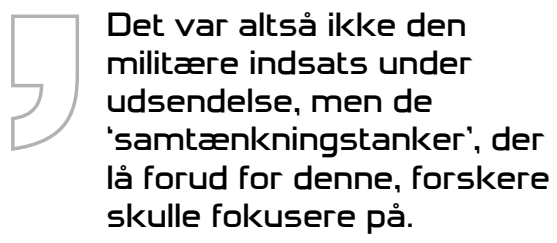

nans er i dag, kommer tydeligt til udtryk i fravalget af informationer om vor militære indsats. Regeringen og det blå flertal har lukket Irakkommissionen. Det har dog med Alternativet vedtaget en 'udredning' af “... baggrunden for Danmarks militære engagement i Kosovo, Irak og Afghanistan ... for at blive klogere på beslutningerne om Danmarks militære engagement". Men bemærk, det er kun 'baggrunden', der skal inddrages og kun ud fra skriftlige, ikke-klassificerede kilder. Altså heller ikke ud fra interviews. Den begrænsede viden der således opnås, reducerer det nødvendige input af 'lessons learned' til skade for den militære effektivitet.

Selv den hidtidige erfaringsopsamling for Afghanistan, som politikerne har tilladt, tillader ikke den militære profession og befolkningen at blive klogere på vore soldaters militære taktiske operationer. For i kommissoriet til DIIS-forskerne har politikerne direkte bestemt, at "erfaringsopsamlingen ikke skal beskæftige sig med militære aktiviteter på det taktiske/operative niveau". Politikerne ønsker blot at få DIIS til at undersøge "Samtænkningen af politiske, udviklingsmæssige og militære indsatser i Afghanistan fra 2001 til 2014".

Det var altså ikke den militære indsats under udsendelse, men de 'samtænkningstanker', der lå forud for denne, forskere skulle fokusere på. Disse tanker blev så fremlagt i DIIS-rapporten Afghanistan. Erfaringsopsamling 2001 - 2014, del I. Heri erkendes, at "fokus i dette studium har vedvarende været på sammenhængen mellem indsatserne og ikke effekten af indsatserne" (side 77). Men hvordan kan man måle en 'samtænkning af indsatser', når den enkelte indsats ikke må måles endsige deres indbyrdes relation?

Lad os tage et konkret eksempel. Det var af koalitionen i Afghanistan bestemt, at ca. 3.200 skoler skulle etableres i landet; heraf stod Danmark for 290. Hvor mange af dem fungerer i dag? og hvilken del af 'samtænkningen' er gået galt, den militære, udviklingsmæssige eller udenrigspolitiske dimension? når man i dag må erkende, at hovedparten af dem ikke fungerer? Når man hverken måler indsatserne, deres indbyrdes relation eller samlede effekt, så er den 'erfaringsopsamling' lige så irrelevant som at få belyst et hospitals indsats ved alene at se på, hvordan lægers, sygeplejerskers, portørers, sanitørers, kontorpersonales arbejde er 'samtænkt'. For det er stadig ikke deres 
konkrete virke, der måles, kun forventningen om deres samarbejde.

\section{De faldne}

Selv når politikerne fravælger en større undersøgelse af den danske militære og anden indsats, burde ét emne være gjort til genstand for en nærmere undersøgelse: De dræbte danske soldater i Afghanistan. 43 danske soldater omkom i Afghanistan, og af dem omkom 25 ved vejsidebomber (knap 60 pct.), dvs. under patruljering fra basen og ud til lokale bebyggelser i Helmand-provinsen. Et andet interessant mønster er, at ni (19 pct.) af dem omkom i måneden marts, ingen i april og kun én i februar og i maj. Så store udsving for nærtliggende måneder er markant, også fordi marts måned ikke var tilsvarende dødelig for soldater fra UK (som vi samarbejdede med i Helmand-provinsen) og USA.

Alene det betydelige antal af omkomne danske soldater berettiger til en nærmere undersøgelse. Dertil kommer, at effekten af de gentagne patruljeringer mellem kaserne og by for nedkæmpelsen af Taleban var begrænset. Når danske soldater vendte tilbage til kasernen om aftenen, overtog Taleban magten lokalt. Endelig må der være en specifik dansk forklaring på marts måneds mange omkomne.

Vi kender ikke årsagen til disse to mønstre (patruljering og marts), som politikerne heller ikke vil undersøge. Deres (og forsvarets) fravalg af information forringer dets effektivitet på slagmarken og troværdighed generelt.

\section{Forsvarsplanlægning/strategi}

Inden for det femte militærsociologiske parameter, forsvarsplanlægning, har politikernes beslutninger især undergravet forsvarets effektivitet.
For det første har danske politikere som sagt fravalgt informationer om vore soldaters krigsindsats, i modsætning til fx UK og Norge, der sidste år udsendte rapporter om deres militære indsats i henholdsvis Irak og Afghanistan.

Danske politikeres fravalg af tilsvarende undersøgelser for Danmarks militære indsatser bliver ikke mindre interessante, når den britiske rapport anfører: "UK og USA's strategier for krigsførelsen (i Irak) begyndte næsten øjeblikkeligt at afvige indbyrdes..." og "mellem 2003 og 2009 var der ikke nogen sammenhængende US/UK strategi for sikkerhedssektorreform-programmet" og den "væsentligste strategi for UK var at reducere dets styrker". Hvad var Danmarks strategi? Fulgte vi UK eller USA eller hvad? Det øger ikke forsvarets slagmarkseffektivitet at ignorere sådanne strategispørgsmål.

For det andet er forsvarets strategiske planlægning nu spredt for flere vinde. Fra november 1972 og til 2006 var ekspertisen samlet i Vedbæk, hvor FC og forsvarstabschef regerede sammen med de tre værns ledelser. Siden 2013 er forsvarsplanlægningen tredelt. Den nu afgåede FC, Peter Bartram, fik formelt tildelt et hovedfunktionsområde 'operation' (generelt, specifikt og arktisk). Men planlægningen af enhver operation kræver indsigt i personel, økonomi og materiel, og de emner var underlagt en koncerndirektør, general Bjørn Bisserup, i Forsvarsministeriet, og dermed underlagt politisk styring. Endelig er hvert af de tre værns operative stabe, som FC formelt skulle lede, blevet samlet i Karup, mens FC altså arbejdede i København. Den struktur øger ikke forsvarets effektivitet.

For det tredje beskar politikerne antallet at FC's funktionsområder. Fra 1970 til 2013 havde en FC mange funktioner (op 


\section{Al sociologisk indsigt viser, at når organisation og profession støder sammen, så vinder organisationen.}

til 50), herefter kun tre: operation (nævnt ovenfor), værnledelse og udvikling. Alligevel fastholdt politikerne, at FC skulle rådgive dem strategisk. Den beslutning viser politikernes despekt for den militære professions ekspertise.

FC vil få svært ved at fremlægge 'den ønskede vare' professionelt, når han har mindre indsigt $i$ og mere distance til strategiske data end koncerndirektøren og de tre operative stabe i Karup. Så den danske FC svækkedes ikke kun internt, men også eksternt i forhold til andre landes forsvarschefer til skade for det internationale militære samarbejde og dermed for den militære effektivitet.

For det fjerde har politikerne reduceret antallet af militære tjenesteder i Danmark under indtryk af det faldende antal værnepligtige og de professionelle soldaters fravalg af at bo på kasernerne. I 1989 var der 641 tjenestesteder i Syddanmark, i dag 275, en nedskæring med 57 pct. Samtidigt har politikerne flyttet tjenestestederne fra hovedstaden, Sjælland og Fyn til Jylland. I 1970 havde Jylland 44 pct. af alle militære tjenestesteder, i dag 54 pct.
Det betyder, at dansk forsvar grundlæggende styres af to centre, et politisk Forsvarsministeriet i København - og et militært - stabene i Karup. Al sociologisk indsigt viser, at når organisation og profession støder sammen, så vinder organisationen.

\section{Forklaring følger}

Når danske politikere er gået så hårdt til forsvaret og ikke mindst de militære topofficerer, kan det opfattes som en tak for sidst til de seneste tre forsvarschefer, der politiserede kraftigt: Christian Hvidt (1996-2002), Jesper Helsøe (2002-2008) og Tim Sloth Jørgensen (2008-2009).

Denne 'politisering' er en anden historie. Men danske politikeres svækkelse af den militære effektivitet må ophøre nu. Hvis politikerne alvorligt mener, at vi skal støtte vore soldater, så kan de starte med sig selv ved at træe flere skridt tilbage og tillade professionelle vurderinger inden de beslutter, herunder hvornår balancen mellem politisk kontrol og militær professionalisme tipper. 


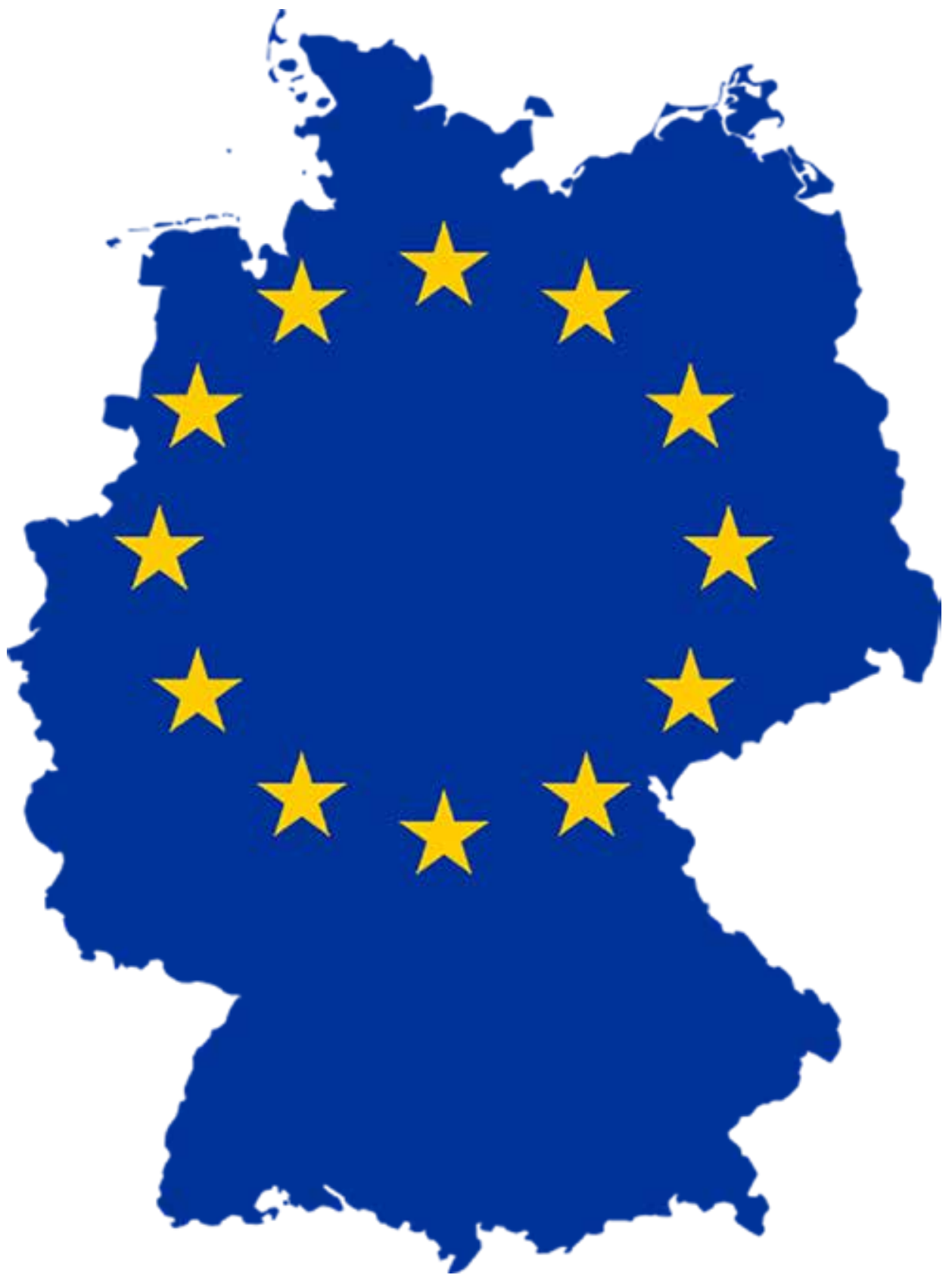

LLUSTRATION: Via Wikimedia Commons

Kort over Tyskland med EU flag

BAGGRUND 